\title{
Studies on the Antibiotic Substances from Actinomyces
}

\author{
(5th Repoart) \\ "Secondary Screening" Test of 15 Strains of Actinomyces, Specially \\ Antagonistic to Acid-fast Bacteria \\ By \\ Masahiko Kuroya, Nakao Ishida, Ken Katagiri, \\ (黑屋政) (石田名香雄) (片 桐誰) \\ Takehiko Shiratori and Reiko Chida \\ (白取㣚䇺) (千田禮子) \\ (From the Department of Bacteriology, Faculty of Medicine, \\ Tohoku University, Sendai) \\ (Received for publication, September 18, 1951)
}

In the first step of the study on the antagonistic actinomyces, 360 active strains") were selected by streak plate method (so-called "primary screening") and classified into 4 groups (Table I).

TABLE I

Classification of 360 Active Strains of Actinomyces

\begin{tabular}{l|l|r}
\hline 1st group & $\begin{array}{l}\text { inhibitory to gram positive, negative } \\
\text { and acid-fast organisms }\end{array}$ & $201(56 \%)$ \\
2nd group & $\begin{array}{l}\text { inhibitory to gram positive and acid- } \\
\text { fast organisms }\end{array}$ & $130(36 \%)$ \\
3nhibitory to gram positive bacteria & $14(4 \%)$ \\
4th group & $\begin{array}{l}\text { only } \\
\text { inhibitory to acid-fast bacteria only }\end{array}$ & $15(4 \%)$
\end{tabular}

For last 2 years many efforts were taken to investigate the 1st group actinomyces (inhibitory to Gram positive, Gram negative and acid fast bacteria) i.e. to divide this group of actinomyces further in details by the specificities of culture filtrates (so-called "secondary screening") 2 ) and to isolate the representative antibiotics of this group in crystalline forms (streptomycin ${ }^{2) 3}$ ) and many streptothricin-like substances $\left.{ }^{4)}\right)$. Many antibiotics belonging to the 1st group inhibited acid-fast bacteria too and especially streptomycin is remarkably potent to My. tuberculosis (human type). Furthermore, Kelner and Morton ${ }^{51}$ reported the isolation of an " anti-smegmatis factor" from the culture filtrate of a strain of actinomyces.

The 4th group actinomyces, however, were so chracteristic in their specific antagonistic activity against acid-fast bacteria, that it was thought 
most interesting to prove their potency in their culture filtrates using several kinds of culture media and to elucidate their specific properties by comparison of their antibacterial spectra with the others according to several methods (cup-, dilution- and superposing method) and of antibacterial activities in test media of several $\mathrm{pH}$.

\section{EXPERIMENTAL}

Methods and Materials

1) Culture media: After many experiments the following media were used in order to prove the antibacterial activities of 15 actinomyces in their culture filtrates:

For surface culture (semi-solid media containing 0.25\% agar)

(1) Modified Waksman media, containing 3\% glucose.

(2) Modified Waksman media, containing 2\% glycerol.

For shaking culture

(1) Modified Waksman media, containing 1\% glycerol.

(2) Modified Waksman media, containing $1-2 \%$ glycerol and $0.35 \% \mathrm{CaCO}_{s}$.

(3) Modified Waksman media, containing 1\% starch.

(4) Original Waksman media, containing $1 \%$ glucose.

2) Assay method: On the 5th, 10th and 15th day in the case of surface culture, and on the 2nd, 4th and 6th day, in the case of shaking culture, samples of each culture fluid were filtered, heated at $100^{\circ} \mathrm{C}$ for 5 minutes and tested for their activities

(1) Dilution method: The culture filtrates were diluted at first 5 or 10 fold and then 2 fold successively with the test medium $44 \%$ glycerol broth, $\mathrm{pH}$ 6.5). Total volume of culture media was $5 \mathrm{cc}$. each. Their activities were tested upon Mycobacterium phlei, My. smegmatis and My. auium starting from 10 fold. For Mycobacterium tuberculosis (human type, Aoyama B strain) modified Lockemann media ( $\mathrm{pH} 6.5$ ) were used starting from 5 fold.

(2) Cup assay: Unheated culture filtrates were filled in the cup at the center on glycerol agar plates and stored in the ice-box overnight. After 24 hours, 7 test bacteria (My. phlei, My. smegmatis, My. avium, My. $s p$. (Clegg type), B. anthracis, Staph. aureus and E. coli) were streaked radially around the cup and incubated at $37^{\circ} \mathrm{C}$ for 2 days. The length of inhibition zone was measured in $\mathrm{mm}$.

(3) One-dimensional diffusion method ${ }^{6}$ ) was also used to test the activity of filtrates on Staphylococcus and E. coli. Because this method was found to be most sensitive to prove the slightest activity on these microorganisms, it was expected to be able to prove by this method the specificity of filtrates to acid-fast bacteria only. 
(4) Filtrates showing activity in dilution method, were assayed again by dilution method using $4 \%$ glycerol broth of $\mathrm{pH} 6.5$ and 7.5 in order to find out a suitable $\mathrm{pH}$ of test medium.

All the results which referred to following 3 points are shown in Tables II, III and IV.

(1) The specificity of antibiotic spectrum of culture filtrates. (dilution method and cup assay)

(2) $\mathrm{pH}$ of test medium, at which culture filtrate was most active.

(3) Diffusibility of antibiotics in cup assay: These observations enabled us to presume the chemical character of antibiotic substance contained in the filtrate.

\section{Results}

1) It was able to prove antibiotic activities in culture filtrates of 11 out of 15 strains, using several kinds of culture media in surface or shaking culture. Though their activity was not so powerful in general, the activity of filtrates in any assay methods corresponded almost with that of "primary screening."

TABLE II

Method of Cultivation

\begin{tabular}{c|l|l|c|c}
\hline Strain No. & $\begin{array}{c}\text { Culture } \\
\text { method }\end{array}$ & Culture media & $\begin{array}{c}\text { Incubation } \\
\text { period } \\
\text { (days) }\end{array}$ & $\begin{array}{c}\text { pH } \\
\text { at maximum } \\
\text { potency }\end{array}$ \\
\cline { 2 - 2 } & shaking & $1 \%$ glycerol $\left(0.35 \% \mathrm{CaCO}_{3}\right)$ & 4 & 7.0 \\
364 & surface & $1 \%$ glycerol & 12 & 7.6 \\
436 & surface & $3 \%$ glucose & 15 & 6.4 \\
497 & surface & $2 \%$ glycerol & 15 & 7.8 \\
\hline $0-30$ & & & 4 & 6.0 \\
$0-101$ & shaking & $1 \%$ glucose & 4 & 9.4 \\
$0-128$ & shaking & $1 \%$ glycerol & 4 & 7.2 \\
\hline 388 & shaking & $1 \%$ glycerol $\left(0.35 \% \mathrm{CaCO}_{3}\right)$ & 6.0 \\
\hline 309 & shaking & $1 \%$ glycerol & 10 & 5.8 \\
\hline 287 & surface & $2 \%$ glycerol & 10 & 8.2 \\
\hline 395 & surface & $3 \%$ glucose & & \\
\hline 450 & & & & \\
\hline 57 & & & & \\
\hline 27 & shaking & $1 \%$ glycerol & & \\
\hline 456 & & & & \\
\hline
\end{tabular}


TABLE III

Classification by the "Primary Screening"

\begin{tabular}{|c|c|c|c|c|c|c|c|}
\hline \multirow{2}{*}{$\begin{array}{l}\text { Strain } \\
\text { No. }\end{array}$} & \multicolumn{3}{|c|}{$\begin{array}{l}\text { Character on asparagin- } \\
\text { glucose agar }\end{array}$} & \multirow{2}{*}{$\begin{array}{l}\text { Chromogenic } \\
(+) \text { or not } \\
(-) \text {, on nut- } \\
\text { rient both } \\
\text { agar }\end{array}$} & \multicolumn{3}{|c|}{$\begin{array}{l}\text { Results of streak plates } \\
\text { (length of inhibition } \\
\text { zone, in } \mathrm{mm} \text { ) }\end{array}$} \\
\hline & Basic mycel. & Aerial mycel. & $\begin{array}{l}\text { Soluble } \\
\text { pigment }\end{array}$ & & Sm.* & Av.* & Phlei* \\
\hline $0-130$ & faint yellow & gray green & - & - & 1.0 & 2.0 & 1.0 \\
\hline 364 & white & gray white & - & + & 3.5 & 8.0 & 7.0 \\
\hline 436 & faint brown & white & yellow & - & 1.8 & 2.5 & 2.0 \\
\hline 497 & faint yellow & gray white & - & - & 0 & 2.3 & 2.0 \\
\hline $0-30$ & faint yellow & red brown & - & + & 5.4 & 3.8 & 3.2 \\
\hline $0-101$ & & white & - & - & 6.7 & 4.5 & 4.0 \\
\hline $0-128$ & faint yellow & yellow brown & - & + & 10.5 & 2.5 & 1.0 \\
\hline 388 & white & white & - & - & 1.0 & 1.0 & 0 \\
\hline 309 & white & rose & - & + & 0 & 6.0 & 6.8 \\
\hline 287 & white & white & - & - & 0 & 1.8 & 4.1 \\
\hline 395 & white & gray brown & - & + & 0 & 0 & 7.0 \\
\hline 450 & faint yellow & gray white & - & - & 0 & 0 & 2.0 \\
\hline 57 & white & gray white & - & + & 0.5 & 0 & 1.0 \\
\hline 27 & faint blue & faint blue & - & + & 0.5 & 0 & 0 \\
\hline 456 & white & white & - & + & 0 & 1.5 & 0 \\
\hline
\end{tabular}

* Sm; indicates My. smegmatis, Av; My. avium, and Phlei; My. phlei.

TABLE IV

Results of "Secondary Screening"

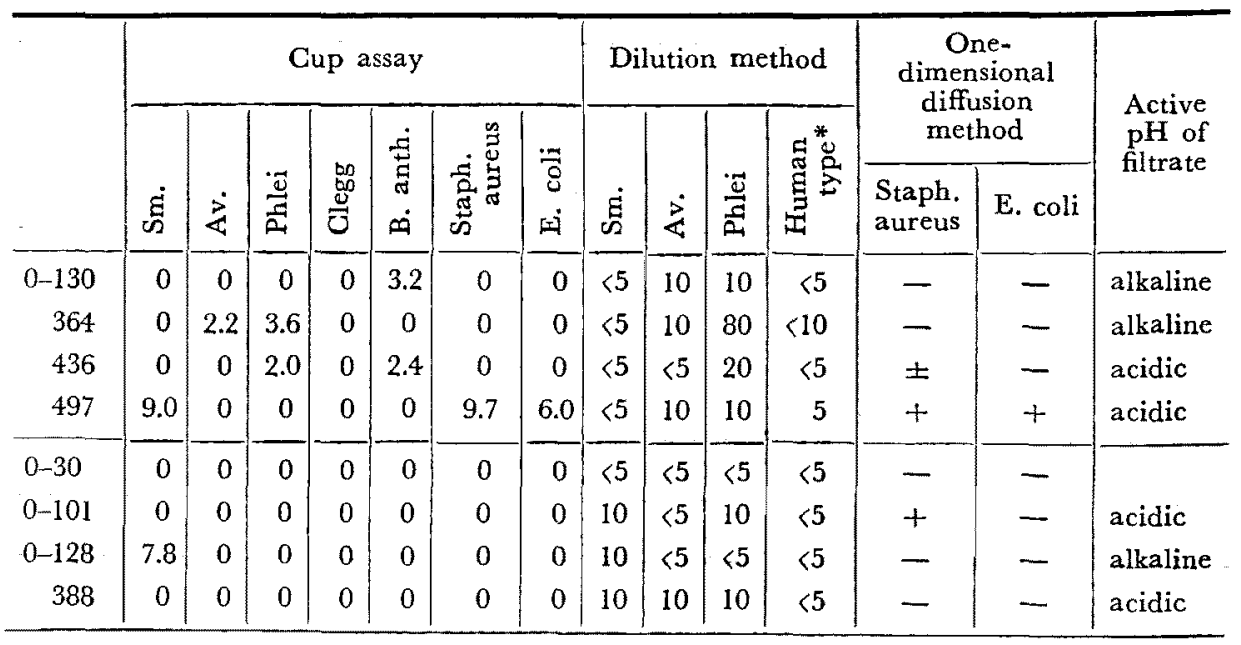




\begin{tabular}{c|c|c|c|c|c|c|c|c|c|c|c|c|c|l}
309 & 0 & 0 & 0 & 0 & 0 & 0 & 0 & $<5$ & 10 & 40 & $<5$ & - & - & acidic \\
287 & 0 & 0 & 4.1 & 0 & 5.1 & 16.3 & 0 & $<5$ & 10 & 20 & $<5$ & + & + & neutral \\
\hline 395 & 5.3 & 0 & 2.3 & 0 & 0 & 0 & 0 & $<5$ & $<5$ & $<5$ & $<5$ & + & - & \\
450 & 0 & 0 & 0 & 0 & 0 & 0 & 0 & $<5$ & $<5$ & $<5$ & $<5$ & - & - & \\
\hline 57 & 0 & 0 & 0 & 0 & 0 & 0 & 0 & $<5$ & $<5$ & $<5$ & $<5$ & - & - & \\
\hline 27 & 0 & 0 & 0 & 0 & 0 & 0 & 0 & $<5$ & $<5$ & 5 & 5 & - & - & acidic \\
\hline 456 & 0 & 0 & 0 & 0 & 0 & 0 & 0 & $<5$ & $<5$ & $<5$ & $<5$ & - & - &
\end{tabular}

* Indicates My. tuberculosis (human type).

2) Although in some cases antibiotic spectra by cup assay method coinsided good with those of "primary screening," they did not in the other. This fact has been already experienced in the screening of the 1st group actinomyces.

3) Antibiotic activity of filtrates was proved in some strains by dilution method only and could not be found out in cup assay, while some were detectable in cup assay only, but could not be proved in dilution method, suggesting different diffusibilities of each filtrate.

4) Filtrate from surface culture were sometimes higher active than that of shaking culture, so both culture methods must be tried in any case.

5) As it was expected, the antibiotic substances produced by 4th group actinomyces were almost not inhibitory to Gram-positive and negative organisms and specially active to acid-fast bacteria only. Some strains of this group, however, showed this specificity only in "primary screening", and in "secondary secrening", they were proved to be somewhat inhibitory to non acid-facst organisms too. In latter case, B. anthracis was often rather sensible than the other, as already anticipated in " primary screening".

6) Properties of active filtrates are somewhat different from each other, showing that all of them may probably produce unknown specific antibiotic substances respectively. A new antibiotic substance specially antagonistic to $M y$. phlei was now isolated and crystallized by Ouchi ${ }^{7}$ from the culture filtrate of Act. No. 364. If each of these antibiotic is purified in the future, they would certainly contribute to reveal the classification and fermentative metabolism of acid-fast bacteria.

7) It was not able to obtain more highly active filtrates to $M y$. tuberculosis (human type) from this group. The 4th group of actinomyces, however, were proved to be very characteristic in the aspect of specific activity to acid-fast organisms. 


\section{Summary}

Fifteen strains which showed a specific activity to acid-fast bacteria only in streak plate method, were tested using several kinds of culture media on their antibiotic potency in the culture filtrates, and studied further on the nature of antibiotic substances from the point of their own antibiotic spectra, active $\mathrm{pH}$ and diffusibility.

\section{References}

1) Kuroya, M., Ouchi, N. and Katsuno, M., Tohoku J. Exp. Med., this volume, p. 203. p. 209.

2) Kuroya, M., Ishida, N., Kobayashi, S., Konno, J., and Chida, R., ibid., this volume,

3) Kobayashi, S., Sato, J., Ishida, N., and Owaki, Y., ibid., 1952, 55, 273.

4) Kuroya, M., Ishida, N., Katagiri, K., Konno, J., Kikuchi, M., and Mizuguchi, R., ibid., 1952, 55, 289.

5) Kelner, A. and Morton, H. E., Proc. Soc. Exp. Biol. and Med., 1946, 63, 227.

6) Ishida, N., Katagiri, K., Chida, R., and Hataya, T., J. Antibiotics (Japanese), 1949, 2, (B), 79 .

7) Ouchi, N., ibid., 1950, 3, 517. 